\title{
Peace Education: A Missing Link in the Adult Education Sub-sector of Ethiopia?
}

\author{
Dessu Wirtu*
}

\begin{abstract}
The purpose of this study was to explore whether peace education has been incorporated into the integrated functional adult education program of Ethiopia. To this end, qualitative research design was employed. Phenomenological approach and qualitative content analysis were used. The required data were obtained from both primary and secondary sources. A total of 53 respondents were selected by using purposive, availability and snow-ball sampling techniques in this qualitative study. Instruments of data collection were semi-structured interview guide, focus group discussion and open-ended questionnaire. The collected data were analyzed, triangulated, and interpreted qualitatively. Bias was overcome by using triangulation, member-checking, and tick description. The findings indicated that peace education as a theme was not integrated into the functional adult education program of Ethiopia even though there are peace education related concepts. It had also identified opportunities to integrate peace education into the educational program and also indicated the challenges like the lack of peace education in academic programs could lead to shortage of qualified professional peace education teachers; and integrating peace education into functional adult education program of the nation might incur huge financial costs. Based on the major findings, it was safely concluded that even though there are some peace education-related contents in the IFAE program, the lack of peace education as an independent theme in the adult education subsector of the country could hamper the development of the required modern conflict resolution techniques among adult learners.
\end{abstract}

Keywords: peace education, integrated functional adult education, stakeholder participation

DOI: https://dx.doi.org/10.4314/ejossah.v14i1.2

*Assistant Professor, College of Education and Behavioral Studies, Addis Ababa University, P O Box: 1176, e-mail: dwirtu@ymail.com, Tel: +251912041575

This work is licensed to the publisher under the Creative Commons Attribution-NonCommercialNoDerivs License. 


\section{Introduction}

\section{Background of the Study}

Modern education was introduced into Ethiopia during the first decade of the $20^{\text {th }}$ century. Likewise, the beginning of modern adult education can be traced back to the same period even though significant attention was given to it since the late 1940s.

This could be seen from the fact that Emperor Haile-Selassie I established the first adult education institution known as "Brehaneh Zare New" (Your light is today) in 1948 and funded it by himself (Tilahun, 2011). Furthermore, the country undertook various literacy initiatives (Ambissa, 2014). For instance, in the 1950s, Ethiopian university students created a literacy movement known as "Yefidel Serawit" (Army of the Alphabet) which managed the provision of basic literacy skills for thousands of adults.

In the 1960s, the Imperial Government invited the UN specialized agencies to get support in designing and implementing the UN Experimental Literacy Project. Accordingly, the experts from UNESCO, UNDP and ILO came to Ethiopia in 1967 and the country implemented the literacy project from 1968 to 1973; nevertheless, the project was evaluated at the end as unsuccessful because of lack of adequate number of literacy experts and due to absence of well documented data for analysis (Dessu, 2006).

During the Dergue Regime, National Literacy Campaign was conducted from 1979 to 1990 (Alemayehu and Jon, 2012). The Campaign was able to mobilize the educated section of the society to teach the illiterate broad mass of the then Ethiopian population and received international recognition for it. However, in its later phase, it turned out to be mere instrument of the political propaganda of the Military totalitarian state and faced vehement resistance from different social groups and the society at large (Ambissa, 2014). On top of that both children and older adults were learning in the same classroom; hence, there was failure in the strategies and techniques of teaching literacy skills.

Since 1991, Ethiopia has become a federal state. The country developed its new Education and Training Policy (ETP) in 1994, which has aimed at solving problems of access, equity, relevance and quality (TGE, 1994:6).

In 2008, the National Adult Education Strategy was launched and today it serves as an important legal basis of adult education in Ethiopia. Furthermore, the country has been implementing a nationwide program known as "Integrated Functional Adult Education" (IFAE). In 2011, the Ministry of Education produced the Curriculum Framework (MOE, 2011) and IFAE Implementation Guidelines. 
Furthermore, UNESCO (2005:6) clearly states that "peace can be cultivated only through training of the mind to control desire, balancing between deserving and desiring, developing tolerance and respect for differences, concern and love for others." Generally, illiteracy is believed to be a direct threat to democracy. Since it is usually the youth and adults who actively participate in violence, rethinking the whole education system in general and the adult education subsector in particular is therefore indispensable. It is on this background that the researcher is interested in doing this research with the aim to explore whether peace education is integrated into the country's integrated functional adult education program or not and thereby to identify opportunities and challenges thereof.

\section{Statement of the Problem}

The Ethiopian Ministry of Education has attempted to integrate peace education into the school curriculum in the academic year 2016/17. A number of researchers conducted studies related to conflict, violence and peace education. For instance, Habtamu Wondimu (2005) explored family violence in Addis Ababa, and indicated that "wife beating and child corporal punishment are major family violence in Addis Ababa. He stressed the need to teach people about peaceful discussions and tolerance". Furthermore, he published his work "Handbook of Peace and Human Rights Education in Ethiopia" in 2010. In the same vein, Tigist Engidaw (2018) analyzed how peace education could contribute to transforming violent behaviors of youth towards culture of peace. However, to the knowledge of the researcher, there wasn't any study conducted directly on the integration of peace education into the Ethiopian integrated functional adult education (IFAE) program. Hence, this study would contribute to closing the existing research gap pertaining to the integration of peace education into the adult education sub-sector.

To this end, the following research questions were set:

(1) Has peace education been integrated into IFAE program of Ethiopia?

(2) What are the opportunities of integrating peace education into the IFAE program?

(3) What are the challenges of integrating peace education into IFAE program of the country? 
Objectives of the study

This study has both general and specific objectives.

\section{General objective}

The overall objective of the study was to explore whether peace education was integrated into curriculum framework of integrated functional adult education.

\section{Specific objectives}

The specific objectives of the study were to:

$\checkmark$ Identify elements of peace education in the themes of the Ethiopian integrated functional adult education.

$\checkmark$ Analyze the opportunities for integrating or scaling up the dimension of peace education into the IFAE.

$\checkmark$ Analyze challenges with regard to integrating or scaling up peace education in IFAE.

\section{Significance of the Study}

The findings of this study may help:

$\checkmark$ Educational policy makers recognize the importance of providing peace education for adults;

$\checkmark$ Curriculum planners think over on ways of integrating peace education into IFAE of the country;

$\checkmark$ Facilitators of IFAE, adult learners and communities at large develop the culture of peace;

$\checkmark$ Initiate other researchers conduct more comprehensive study in the area.

\section{Scope of the Study}

In this study, the respondents were drawn only from public institutions (Ministry of Education, public universities, and professional NGOs. Furthermore, the investigation pertains only to the integration of peace education in IFAE program of the nation, the opportunities and challenges thereof. Finally, in order to make the study manageable, the private sector and faith-based organizations were not included in this study. 


\section{Definitions of Key terms}

Peace education: refers to "the process of acquiring the values, the knowledge and developing the attitudes, skills and behaviors to live in harmony with oneself, with others, and with natural environment" (Danesh, 2011).

Violence refers to 'any form of behavior by an individual that intentionally threatens to or does cause physical, sexual or psychological harm to others or themselves' (Stanko, 2001: 316).

\section{Review of the Related Literature The concept of Adult Education}

Adult education was defined differently by a number of scholars at different times. In this study, the definition of adult education which was developed during the Fifth International Conference on Adult Education in Hamburg, Germany in the year 1997 was employed. It states that adult education:

\section{... is a powerful concept for fostering ecologically sustainable development, for promoting democracy, justice, gender equity, and scientific, social and economic development, and for building a world in which violent conflict is replaced by dialogue and a culture based on justice (UNESCO, 1997a:1).}

This definition has been more widely used today because it underlined the importance of adult education for improving the human conditions. Today, the world has faced tremendous environmental crisis, the crisis of development in light of increased poverty in many parts of the world and the growing global insecurity (Kirkby, 1995). The need for fostering the culture of peace, tolerance and dialogue has become clear and evident today more than ever. Plurality, diversity and heterogeneity have changed the political, social and cultural landscape of every nation. Hence, adult education can undoubtedly serve as a tool for enhancing intercultural as well as multicultural competence of individuals and social groups.

\section{Purpose of Adult Education}

The purpose of adult education is highly diverse as there are diverse forms of adult education. Generally, it can:

- Provide basic literacy skills in reading, writing and numeracy;

- Empower adults and promote the development of positive self-image among themselves; 
- Increase their employability prospects when coupled with practical/vocational skill training;

- Raise the life skills of adults, for example, it enables them to be aware of how to prevent themselves from HIV; and how to peacefully resolute conflicts;

- Provide them with the opportunity to learn new skills like application of ICT in their daily lives;

- Help them become more productive in workplaces;

- Raise their environmental awareness;

Hence, it is vital that Ethiopia has been making the necessary efforts to promote the development of adult education. It has embarked on expansion of university adult education both in the undergraduate and graduate programs. In addition, it has launched a nationwide "integrated adult education program" which aims at improving the livelihood of adults and thereby the families. However, in light of scarcity of financial resources a wide range of adult education activities require what Faure (1972: xxxvi) calls "international solidarity and world cooperation".

\section{The Concepts of Peace and Peace Education}

A number of scholars have emphasized the need to distinguish between the following concepts of peace. For instance, Barash and Webel (2002: 6) argue that "Negative peace which refers to the absence of war. It denotes a condition in which no active, organized military violence is taking place."

Positive peace which refers to a social condition in which exploitation is minimized or eliminated, and in which there is neither overt violence nor the more subtle phenomenon of underlying structural violence.

Peace education plays a crucial role in promoting peace. Danesh (2011: 18) states that "Peace and education are inseparable aspects of civilization. No civilization is truly progressive without education, and no education system is truly civilizing, unless it is based on the universal principles of peace."

Ethiopia needs sustainable peace to come out of the vicious circle of poverty which is mainly attributed to continuous civil strife and wars in much of its history. The significance of promoting peace by creating peaceful and inclusive societies is also stressed in Goal 16 of the United Nations Sustainable Development Goals which covers the period between 2016-2030 (Hinzen and Robak, 2017: 5). 


\section{Violence}

The prominent peace studies scholar Johan Galtung (1969) as cited in Carreira, et al. (2014: 33) identified the following three concepts of violence:

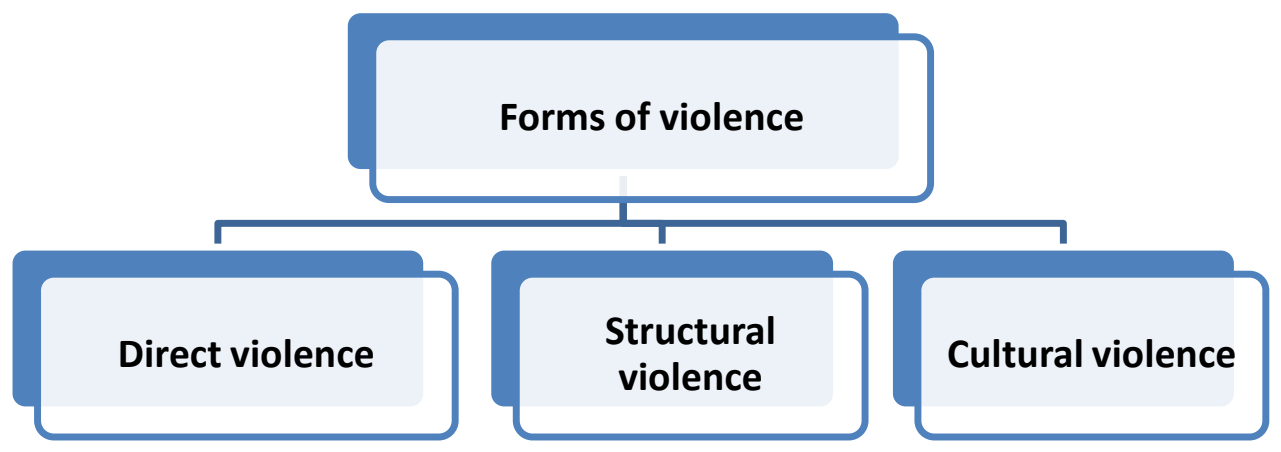

Figure 1: Adapted from the work of John Galtung

Direct violence refers to the most visible form of violence. It includes physical injury, killings, bullying, etc.

Structural violence refers to usually hidden and systematic ways of preventing social groups from access to equal opportunities. For instance, during the Imperial Period in Ethiopia, women were not allowed to inherit land. This was due to lack of legal structures that would ensure equality of men and women.

Cultural violence refers to the existence of certain beliefs and norms that are generally accepted and reproduced in the society without any critical reflection.

Violent conflicts occur in many parts of the world including the Horn of Africa. In her research study, Muhabie (2015: 31-33) indicated the root causes of conflict in the Horn of Africa. She identified economic, historic, social, cultural and political causes.

Likewise, Alagaw (2012: 84-93) identified the following challenges to democracy: authoritarian political culture, lack of genuine citizens' participation in political processes, the country's geo-political position, lack of inclusiveness, and lack of separation between party and government, However, both authors didn't directly mention that illiteracy is also a direct threat to democracy. Illiterate adults for example don't have adequate knowledge and skills concerning their political rights and duties as citizens. Moreover, they are direct victims of social violence. Here, one can see the relevance of the idea that 'reading the word is reading the world' (Freire, 1970). This implies that there is logical nexus between peace education and adult education. 


\section{Curriculum Integration}

Today, the importance of curriculum integration has become more and more significant because it is assumed that the use of diverse interrelated theories, models, conceptions and methods is more appropriate for addressing crosscutting issues. Fogarty (1991) indicated diverse forms of curriculum integration and she deduced that integrated curriculum helps learners see interconnectedness among disciplines. Likewise, Franzie L. Lopp (1999) as cited in Dessu, Getahun, Kalkidan and Tilahun (2014:20) mentioned "curriculum integration models include interdisciplinary, problem-based and theme-based approaches. "When one looks at the Ethiopian integrated functional adult education program, a theme-based approach has been employed because selected themes were included in the curriculum framework which was prepared by the Federal Ministry of Education in 2011.

Nevertheless, the concept of peace was not included as one of the themes in the integrated functional adult education. Since curriculum is basically influenced by philosophy, psychology and sociology and culture, curriculum integration should consider them adequately. This idea is related to what the prominent peace educator Danesh (2011) calls worldviews. He posits that the integration of peace education into other disciplines needs to consider the culture of the society or communities. Furthermore, he argues that the basis of every culture is its worldview. Accordingly, he identified the following meta categories of worldview: 


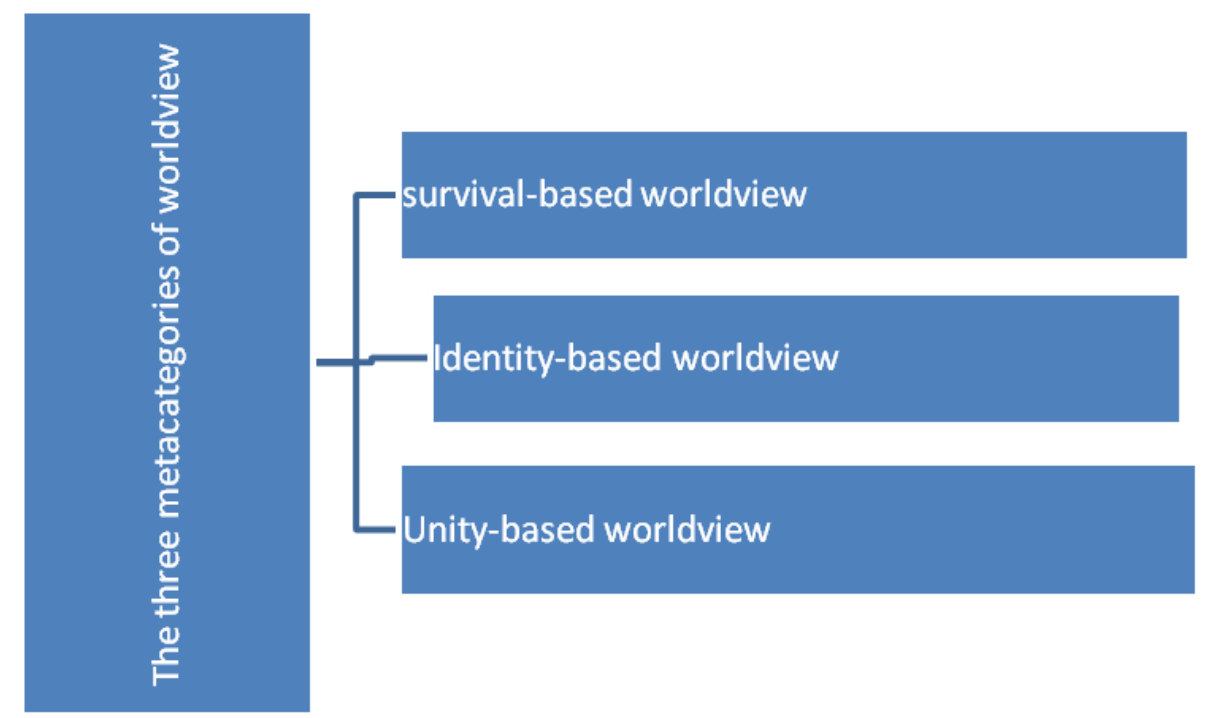

Figure 2: Adapted from the work of H.B. Danesh, 2011

He argues that worldviews are shaped by life experiences and cultural histories (Danesh, 2011:27) and accordingly,

(a) The survival-based worldview corresponds to 'agrarian and pre-industrial stages of the development' of a society. It develops in a situation where there are direct and structural violence.

(b) The identity-based worldview usually develops in a society that emerges from 'authoritarian environments and attempts to create democracy'.

(c) The unity-based worldview is based on the idea of the oneness of humanity. Here, a 'society operates according to the principle of unity in diversity'.

The nexus between peace education and adult education lies in the fact that adult education can serve as a forum where adult learners reflect on their life experiences and exchange their worldviews. Adults can learn from each other and they can shape their individual and social behaviors. 


\section{Materials and Methods \\ Design and Methods}

The purpose of this paper was to investigate whether peace education has been integrated into the integrated functional adult education of the country. To this end, qualitative research design (Creswell, 2009) was employed because it is appropriate to elicit and generate in-depth information from relatively small number of respondents. Likewise, Maxwell's (1996:5), design refers to "arrangements of the elements governing the functioning of the study". Based on the design, qualitative methods were used. According to Stake (2010:18), "qualitative research methods are built around experiential understanding." In this study, phenomenological approach and qualitative content analysis were used. The Phenomenological approach helps conduct interviews, read documents, or visit places and events, to understand the meaning participants place on whatever's being examined (Best and Kahn, 1993) whereas the qualitative content analysis is employed by using a category system which is regarded as the central instrument of analysis (Mayring, 2014).

\section{Sources of Data}

Both primary and secondary sources of data were used in this study. The primary sources were adult and non-formal education experts of the Ministry of Education, adult education experts from professional NGOs, adult education instructors, and graduate students. The secondary sources included relevant policy documents.

\section{Sample Size and Sampling Techniques}

There are no specific rules that should be used in determining the sample size in qualitative research. Qualitative sample size may best be determined by the time allotted, resources available, and study objectives. Glaser and Strauss (1967) as cited in Gentles, Charles, Ploeg \& McKibbon (2015) recommend the concept of saturation for achieving an appropriate sample size in qualitative studies.

A total of fifty-three respondents were used as respondents in this qualitative research:

- Five adult and non-formal education experts from the Ministry of Education;

- One education expert of Adult and Non-Formal Education Association in Ethiopia;

- One education expert of UNESCO Cluster Office in Addis Ababa were selected by using purposive sampling technique; whereas; 
- Two adult education experts from DVV International were selected by using snow-ball sampling technique;

- Four regional IFAE focal persons from four regions, namely, Amhara, Tigray, SNNPR, and Addis Ababa City Administration;

- Ten woreda IFAE focal persons from five regions that include Amhara, Tigray, SNNPR, Addis Ababa City Administration and Oromia;

- Ten adult education instructors from five public universities, and

- Twenty graduate students from Addis Ababa University were selected by using availability sampling.

\section{Instruments of Data Collection}

Instruments of data collection were semi-structured interview guide, focus group discussion and open-ended questionnaire. The semi-structured interview guide was employed to collect data from respondents drawn from the Ministry of Education, UNESCO Cluster Office, and Ethiopian Adult and Non-Formal Education Association in Ethiopia (ANFEAE) whereas focus group discussion was used to gather information from graduate students of Curriculum and Instruction, Vocational Education Management, and Political Science and International Relations at Addis Ababa University. In addition, open-ended questionnaire was used to generate information from:

$\checkmark$ Adult education experts from DVV International.

$\checkmark$ Adult education focal persons from Amhara, Tigray, SNNPR, and Addis Ababa City Administration.

$\checkmark$ Woreda adult education focal persons from Amhara, Tigray, SNNPR, Oromia and Addis Ababa City Administration..

$\checkmark$ Adult education instructors from five Ethiopian public universities

$\checkmark$ Graduate students from Addis Ababa University.

\section{Results and Discussions}

\section{Background Information of Respondents}

A total of fifty-three respondents were used in this qualitative research, namely:

$\checkmark$ five adult and non-formal education experts from the Federal Ministry of Education,

$\checkmark$ four IFAE regional focal persons from Amhara, SNNPR, Tigray and Addis Ababa, 

$\checkmark$ ten woreda IFAE focal persons who came from five regions, namely Amhara, SNNPR, Tigray, Oromia and Addis Ababa,
$\checkmark$ ten adult education instructors drawn from five public universities, namely Bahir Dar University, Hawassa University, Ambo University, Arba Minch University and Addis Ababa University;
$\checkmark$ twenty graduate students from the Department of Curriculum and Instruction, and Department of Political Science and International Relations,
$\checkmark \quad$ two adult education experts from DVV International,
$\checkmark$ one UNESCO education expert, and
$\checkmark$ one adult and non-formal education expert from Adult and Non-formal Education Association in Ethiopia (ANFEAE) who were included by using snow-ball sampling technique.

Concerning gender of respondents, twelve of the respondents in this study were female whereas forty-one of them were male. In terms of their educational qualifications, two of the respondents were PhD holders; twelve of them had master's degree, whereas twenty-nine of them had first degree.

\section{Peace Education in Ethiopian IFAE Program}

Peace education is not adequately integrated into the integrated functional adult education of Ethiopia. This can be seen from the following words of adult and nonformal education expert of the Ethiopian Ministry of Education (ANFEE-MOE-1):

There are peace education related contents in the integrated functional adult education of Ethiopia. From the themes of the IFAE Curriculum Framework, elements of peace education are found mainly in two of the themes, namely in Civics and Ethics and Social Life. For instance, topics related to the former include democratic rights, building a democratic society, rule of law, equity and equality, patriotism, and work culture whereas topics related to the latter include methods of conflict resolution and conditions for development.

Likewise, an instructor of adult education and community development from Bahir Dar University (BUD-1) reported: 
I don't personally believe this critical element is entertained in the program except some components like Ethics. Peace education is not owed with the space it deserves despite its profound value in equipping adults with relevant skills and behaviors to harmoniously live together with each other.

In the same vein, one of the woreda IFAE focal persons pointed out in the open-ended questionnaire that there are some issues related to peace education in the integrated functional adult education program of the nation even though they are not adequate. Specifically, peace education related contents are found within the themes of civics and ethics, gender and social life. In addition to this, qualitative content analysis was conducted. The units of analysis were themes of the Integrated Functional Adult Education Curriculum Framework. It consists of eight themes under which topics and subtopics were indicated as categories. In order to see the relevance of these themes (topics and subtopics) to peace education, criteria were developed in the form of peace education categories and presented by using the following two tables.

Table 1: Categories of Agriculture, Health, Income Generation and Civics and Ethics

\begin{tabular}{|l|l|l|l|}
\hline No. & Theme (topic and subtopics) & $\begin{array}{l}\text { Presence of peace education related concepts } \\
\text { (peace, peaceful co-existence, conflict, conflict } \\
\text { resolution, democratic rights and values, } \\
\text { mediation, arbitration, respect for others, gender } \\
\text { equality, environmental protection, tolerance, } \\
\text { critical thinking, problem solving methods, } \\
\text { violence, dialogue, the culture of peace) }\end{array}$ & $\begin{array}{l}\text { peace education } \\
\text { the }\end{array}$ \\
\hline 1. & $\begin{array}{l}\text { Agriculture (Crop farming, } \\
\text { livestock farming, natural } \\
\text { resource development, } \\
\text { farming in urban } \\
\text { communities like horticulture } \\
\text { farming, dairy farming, } \\
\text { poultry farming) }\end{array}$ & Natural resource development & $\begin{array}{l}\text { Relevant, but not } \\
\text { explicitly } \\
\text { indicated. }\end{array}$ \\
\hline 2. & $\begin{array}{l}\text { Health (family health, } \\
\text { prevention and control of } \\
\text { HIV/AIDS, hygiene and the } \\
\text { state of local health care) }\end{array}$ & $\begin{array}{l}\text { Prevention and control of HIV/AIDS, rights of } \\
\text { women, sexual violence, hygiene. }\end{array}$ & $\begin{array}{l}\text { Relevant, but not } \\
\text { adequately and } \\
\text { explicitly } \\
\text { indicated. }\end{array}$ \\
\hline 3. & $\begin{array}{l}\text { Income generation } \\
\text { vegetable garden, small }\end{array}$ & vegetable garden, saving & $\begin{array}{l}\text { Relevant but not } \\
\text { explicitly }\end{array}$ \\
\hline
\end{tabular}




\begin{tabular}{|c|c|c|c|}
\hline & $\begin{array}{l}\text { scale trade, handicraft, } \\
\text { saving, job creation, } \\
\text { cooperative work, food } \\
\text { preservation techniques) }\end{array}$ & & indicated \\
\hline 4. & $\begin{array}{l}\text { Civics and Ethics } \\
\text { (democratic system, the } \\
\text { supremacy of the law, equity, } \\
\text { justice, responsibility, work } \\
\text { culture, self- reliance, } \\
\text { participation, the rights of } \\
\text { children, women and persons } \\
\text { with disabilities, the structure } \\
\text { of the federal system ) }\end{array}$ & $\begin{array}{l}\text { Democratic system, the supremacy of the law, } \\
\text { equity, justice, responsibility the rights of children, } \\
\text { women and persons with disabilities, the structure } \\
\text { of the federal system }\end{array}$ & $\begin{array}{l}\text { Relevant and } \\
\text { adequately } \\
\text { indicated } \\
\text { explicitly } \\
\text { indicated. }\end{array}$ \\
\hline
\end{tabular}

Table 2: Categories of environment, gender, social life and critical thinking

\begin{tabular}{|c|c|c|c|}
\hline No. & Theme (topic and subtopics) & $\begin{array}{l}\text { Presence of peace education related concepts } \\
\text { (peace, peaceful co-existence, conflict, conflict } \\
\text { resolution, democratic rights and values, } \\
\text { mediation, arbitration, respect for others, gender } \\
\text { equality, environmental protection, tolerance, } \\
\text { critical thinking, problem solving methods, } \\
\text { violence, dialogue, the culture of peace) }\end{array}$ & $\begin{array}{l}\text { Interpretation of } \\
\text { the relevance of } \\
\text { the themes to } \\
\text { peace education }\end{array}$ \\
\hline 5. & $\begin{array}{l}\text { Environmental } \\
\text { conservation and } \\
\text { management (Preventing } \\
\text { draught, environmental } \\
\text { pollution, deforestation, fuel } \\
\text { efficient stoves, bio-gas) }\end{array}$ & $\begin{array}{l}\text { Preventing draught, environmental pollution, } \\
\text { deforestation, fuel efficient stoves, bio-gas } \\
\text { (environmental protection) }\end{array}$ & $\begin{array}{l}\text { Relevant, but mot } \\
\text { so explicitly } \\
\text { indicated. }\end{array}$ \\
\hline 6. & $\begin{array}{l}\text { Gender (gender equality, } \\
\text { sexual harassment, } \\
\text { abduction, female } \\
\text { circumcision, rape/sexual } \\
\text { violence, early marriage, } \\
\text { problems of adolescence and } \\
\text { their solution) }\end{array}$ & $\begin{array}{l}\text { Gender equality, sexual violence, abduction, } \\
\text { female circumcision and early marriage (rights of } \\
\text { women) }\end{array}$ & $\begin{array}{l}\text { Relevant and } \\
\text { explicitly } \\
\text { indicated. }\end{array}$ \\
\hline 7. & $\begin{array}{l}\text { Social life (child labor and } \\
\text { exploitation, marriage by } \\
\text { abduction, Idder and Iqqub, } \\
\text { child rights, rights of } \\
\text { persons with disabilities, } \\
\text { care of elderly, elevating the } \\
\text { culture of work, urban }\end{array}$ & $\begin{array}{l}\text { Child rights, rights of women, respect for each } \\
\text { other (Care for elderly, Idder and Iqqub), urban } \\
\text { migration of children, critical thinking (useful } \\
\text { cultures and harmful practices). }\end{array}$ & $\begin{array}{l}\text { Relevant and } \\
\text { explicitly } \\
\text { indicated. }\end{array}$ \\
\hline
\end{tabular}




\begin{tabular}{|l|l|l|l|}
\hline & $\begin{array}{l}\text { migration of children, youth } \\
\text { and adults, useful cultures, } \\
\text { and harmful practices) }\end{array}$ & & \\
\hline 8. & $\begin{array}{l}\text { Critical thinking, (Problem } \\
\text { solving methods, solving } \\
\text { conflict through dialogue, } \\
\text { development, enhancing } \\
\text { awareness and self- } \\
\text { confidence) }\end{array}$ & $\begin{array}{l}\text { Problem solving methods, solving conflict through } \\
\text { dialogue, development, enhancing awareness and } \\
\text { self-confidence, critical thinking. (Highly relevant) }\end{array}$ & $\begin{array}{l}\text { Relevant and } \\
\text { explicitly } \\
\text { indicated, }\end{array}$ \\
\hline
\end{tabular}

From the above tabular descriptions, it is observed that from the eight themes of the Ethiopian Integrated Functional Adult Education Curriculum Framework, only the themes 'Civics and Ethics', 'Gender', 'Social life', and 'critical thinking' explicitly deal with contents related to peace education whereas agriculture, health, income generation, and environmental conservation and management didn't explicitly deal with contents related to peace education. However, these are inadequate as vital aspects of peace education like the concepts of peace, types of violence, conflict, conflict resolution techniques etc. are not included as topics and subtopics.

\section{Opportunities for Integrating Peace Education into IFAE Program}

Peace and conflict have become global issues today. Peace and conflict in any part of the world have direct or indirect impact on lives of societies in other parts of the world. While globalization has undeniably brought some positive values, Ashok Swain, Ramses Amer, and Joakim Ojendal (2008:1) argue, it has created "social and internal conflicts, ethnic strife, political instability (often related to democratization), pauperization, forced migration and rampant natural resource extraction with severe livelihood losses for millions, just to mention a few of the far too prevalent problems."

Concerning the opportunities for integrating peace education into the IFAE program, focus group discussants pointed out the following:

* The existence of appropriate government structure;

* The existence of growing number of public higher education institutions that could provide support to the program in various ways;

* The existence of internationally prominent professional organization that has been providing support to Ethiopian adult education since 1995 DVV International; 


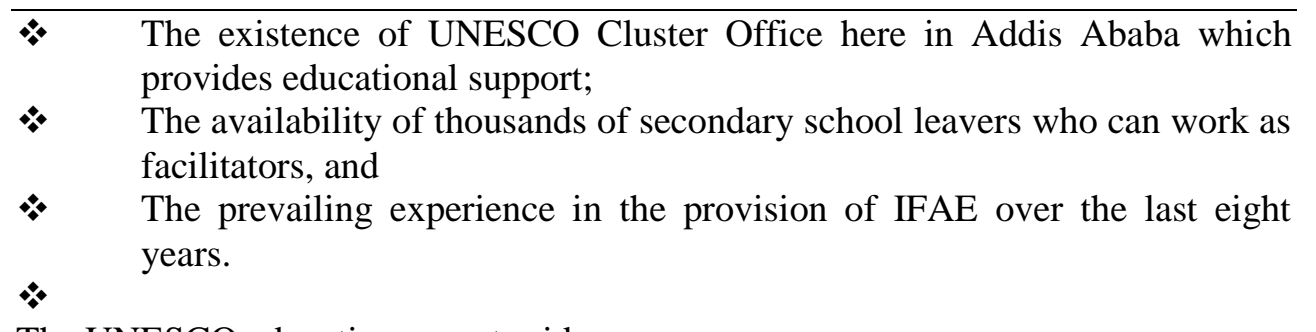

The UNESCO education expert said:

\begin{abstract}
In the Preamble of its Constitution, UNESCO has already emphasized the importance of peace by saying 'Since wars begin in the minds of men, it is in the minds of men that the defense of peace must be constructed.' Therefore, it is necessary to integrate peace education contents into the integrated functional adult education of Ethiopia. However, it requires adequate planning.
\end{abstract}

Likewise, the IFAE focal persons from the five regions mentioned the following benefits:

- It promotes the inner peace of individual adults,

- It enhances family peace,

- It raises awareness of adults about the importance of peace, tolerance, equity and equality,

- It promotes socio-economic development,

- It encourages the culture of peaceful conflict resolutions.

In the same vein, adult educators from public universities reported in the open-ended questionnaire that there are ample opportunities for integrating peace education contents into the IFAE program of the country since there are today relatively adequate numbers of curriculum experts and well experienced adult educators, who can facilitate its implementation by closely working with international peace education experts.

Similarly, Coy (2009: 71) argues as follows:

The training and building up of local capacities for conflict resolution and transformation are privileged today instead of the intervention of "neutral" or "objective" outsiders as prominent third parties. 
Hence, one can safely conclude that there are opportunities for integrating peace education contents into IFAE of Ethiopia and peace education for adults play a crucial role in promoting social cohesion, non-violence, and the culture of peace.

\section{Challenges in the Integration of Peace Education into the Adult Education Sub-sector}

Despite the fact that democracies and democratic political culture are recently emerging in Africa, promoting the culture of peace is not an easy task. With regard to this issue, Nhema (2004: 13) posits: "Most African countries have yet to succeed in creating a relationship between the state and society that subordinates politics to law and one that provides legal safeguards for rights and liberties consistent with a sustainable democratic order."

Even though integrating peace education into IFAE programs has a number of benefits, there are also some challenges. With regard to the challenges, one of the respondents from the Federal Ministry of Education (ANFE-MOE-2) reported:
Integrating peace education contents into integrated functional adult education of the country is useful; however, it might incur additional costs for the preparation of textbooks, teacher's guide, and supplementary learning materials, the training and retraining of curricular planners and developers, and the development of specific monitoring and evaluation of the program.

Likewise, respondent adult education instructors identified the following challenges in the open-ended questionnaire that the incorporation of peace education into integrated functional adult education requires the engagement of diverse stakeholders (line ministries, faith-based organizations, civic societies, communities, universities, schools, etc.) which is not a simple task, since the culture of using inter-sectoral approach is not well developed in Ethiopia. Furthermore, graduate students pointed out the following challenges during the focus group discussions:

$\checkmark \quad$ It requires training and retraining of facilitators of IFAE and adult educators at colleges of teacher education and universities, which incurs additional costs.

$\checkmark \quad$ It requires clarification of the concept of peace which might mean different things among the diverse cultures of the country.

$\checkmark \quad$ It requires the preparation of minimum learning competencies by professional peace educators. 


\section{Summary, Conclusion and Implications \\ Summary}

The purpose of this study was to explore the integration of peace education into the integrated functional adult education program of the country. To this end, qualitative research design was employed and primary data were collected from a total of fifty-three respondents. In addition, secondary data were obtained from relevant policy documents and related literature.

Purposive, snow-ball and availability sampling techniques were used to select the respondents. Data gathering instruments were semi-structured interview guide, focus group discussion, and open-ended questionnaire. The collected data were analyzed qualitatively. Triangulation, tick descriptions and member checking were used to overcome biases. Furthermore, tick descriptions were made to elucidate ideas and perspectives.

The data analysis led to the following major findings:

(1) The study revealed that peace education as an independent themes was not included in the curriculum framework of integrated functional adult education even though there are some peace education related concepts;

(2) It was found out that the existence of different conceptions of peace among the diverse cultures of Ethiopian peoples might make conceptual clarity difficult.

(3) The study indicated that integrating peace education into integrated functional adult education program helps the country maintain the nationally cherished values like religious tolerance, integrity, kindness, generosity and truthfulness.

(4) It was found out that peace education helps adults develop modern skills of conflict resolution so as to enhance peace building.

(5) It was found out that the existence of colleges of teacher education in the regions could be seen as an opportunity for promoting the integration of peace education into integrated functional adult education program, for they can be used in the training and retraining of facilitators.

(6) The existence of indigenous knowledge of conflict resolution mechanisms in Ethiopia would be seen as an opportunity to integrate peace education into the integrated functional adult education program. 
(7) The study revealed that lack of peace education academic programs could be a challenge with regard to having the required professional peace education teachers.

(8) The study indicated that incorporating peace education into the integrated functional adult education program of the nation might incur huge financial costs.

\section{Conclusion}

Based on the findings, it was safely concluded that the lack of adequate peace education contents in the adult education subsector of the country might lower the general awareness of the society about the culture of peace and modern conflict resolution skills, and this in turn would increase the vulnerability of the population to incessant conflicts that hamper socio-economic growth and cultural transformation.

\section{Implications}

Based on the major findings and the conclusion drawn, it was recommended that

- The Ethiopian Ministry of Education is advised to facilitate the integration of peace education into the Curriculum Framework of integrated functional adult education program.

- Major stakeholders of adult education like regional education bureaus, DVV International, UNESCO Cluster Office, Adult and Non-Formal Education Association in Ethiopia, Universities and Teacher Education Colleges, faithbased organizations as well as the Private Sector are advised to play a significant role in the integration of peace education into integrated functional adult education through active participation in the processes of planning, coordinating, organizing, monitoring and evaluation.

- Universities and colleges of teacher education are advised to work towards the integration of peace education into teacher education curricula.

- The Ministry of Education and regional education bureaus are advised to initiate the integration of peace education into the integrated functional adult education program of the country.

- The Ministry of Education is advised to develop a peace education training manual and guidelines that would be used in the training of adult educators and facilitators of integrated functional adult education program. 


\section{References}

Alagaw, Ababu. (2012). "Entrenching the Culture of Peace in Ethiopia: Challenges and Opportunities" in Anthology of Peace and Security Research, vol. 3, pp. 84-93. Addis Ababa: Institute for Peace and Security Studies in Collaboration with Friedrich Ebert Stiftung.

Alemayehu , Bishaw and Jon, Lasser. (2012). "Education in Ethiopia: Past. Present and Future Prospects." African Nebula, (5): 53-69.

Ambissa, Kenea (2014). "Adult Basic Literacy "Initiatives" in Ethiopia: Change and Continuity." Journal of Critical Education Policy Studies, 4 (1): 374-398.

Barash, D.P. and Webel, Ch. P. (2002). Peace and Conflict Studies. Thousand Oaks: Sage Publications.

Best, J. W. and Kahn, J.V. (1993). Research in Education ( $7^{\text {th }}$ ed.). New Delhi: Princeton Hall.

Carreira, S.A. et al. (2014). Mainstreaming Peace Education: Methodologies, Approaches and Visions. A Practitioner's Manual. European Intercultural Forum e.V., Berlin, Germany.

Coy, P.G. (2009). "Conflict Resolution, Conflict Transformation and Peace building" in McElwee, T.A. and Hall, B.W., Liechty, J. and Garber, J., editors. Peace, Justice, and Security Studies: A Curriculum Guide ( $7^{\text {th }}$ Ed.) London: Lynne Rienner Publishers.

Creswell, J. W. (1998). Qualitative inquiry and research design: Choosing among five traditions. Thousand Oaks, CA: Sage Publications.

Creswell, J.W. (2009). Research Design: Qualitative, Quantitative and Mixed Methods Approaches ( $3^{\text {rd }}$ Ed.). Los Angeles: Sage Publications.

Danesh, H.B. (2008). The Education for Peace Integrative Curriculum: concepts, contents and efficacy, 5(2): 157-173.

Dessu Wirtu, Getahun Kassa, Kalkidan Aberra and Tilahun, Fanta. (2014). Curriculum Assessment on the Integration of Child Rights into the Curricula of Social Science Graduate Programs of Addis Ababa University. Center for Human Rights of Addis Ababa University.

Dessu, Wirtu (2006). Provision of Adult Education in Ethiopia: Trends and Prospects (pp, 402-423), in Proceedings of the Conference on Teacher Education for Sustainable Development in Ethiopia, May 5-6, 2006, Ethiopian Management Institute, Debre Zeit. Glaser, B. G. \& Strauss.

Freire, P. (1970). Pedagogy of the Oppressed. New York: Continnum.

Glaser, B.G \& Strauss, A. L. (1967). The discovery of grounded theory: Strategies for qualitative research. Piscataway, New Jersey: Transaction. 
Ebeye, T., Nworie, G. O. and Ukponu, L. N. (2014). "Utilization of Peace Education in Adult Literacy Programmes in Anambra State for Conflict Resolution and National Security." African Research Review: An International Multidisciplinary Journal, Ethiopia, Vol. 8(4): 166-182. DOI: http://dx.doi.org/10.4314/afrrev.v8i4.1

Faure, E. (1972). Learning to Be: The World of Education Today and Tomorrow. UNESCO

Fogarty, R. (1991). The Mindful School: How to Integrate the Curricula. Palatine, IL: Skylight Publications

Gentles, S. J., Charles, C., Ploeg, J., \& McKibbon, K. (2015). Sampling in Qualitative Research: Insights from an Overview of Literature.

Retrieved from: http://nsuworks.nova.edu/tqr/vol20/iss11/5. Accessed on March 4, 2018.

Giannoukos, G. et al. (2015). "The Andragogy, the Social Change and the Transformative Learning Educational Approaches in Adult Education." Journal of Education and Practice, 6(10): 46-50.

Habtamu Wondimu (2005). "Family Violence in Addis Ababa: Challenges of reconciling culture and human rights in Ethiopia." Journal of the Social Sciences and Humanities (EJOSSAH), 3 (2): 27-50.

Hinzen, H. and Robak, S. (2017). "Inclusion and diversity: Setting the agenda." Dvv International, 84. Bonn, Germany: 4-9.

Julius, K. M., Ngao, G., David, M. and Paul, M. (2012). "Peace Education for Sustainable Peace and Development: A Case of Kenya." Journal of Research in Peace, Gender and Development, 2(2): 028-033.

International Education for Peace Institute. (2011). Education for Peace Integrative Curriculum series (vol. 4). Victoria, Canada: EEP Press.

Kirkby, John et al. (Eds.). (1995). The Earth Scan Reader in Sustainable Development: London, Earthscan Publications Ltd.

Maxwell, J.A. (1996). Qualitative Research Design: An Interactive Approach. New London: Thousand Oaks.

Mayring, Philipp. (2014). Qualitative content analysis: theoretical foundation, basic procedures and software solution. Klagenfurt. URL: http://nbnresolving.de/urn:nbn:de:0168-ssoar-395173

MOE. (2011). Integrated Functional Adult Literacy Curriculum Framework. Addis Ababa.

Muhabie Mekonnen. (2015). "The Root Cause of Conflicts in the Horn of Africa." American Journal of Applied Pyschology, 4(2): 28-34.

doi:10.11648/j.ajap.20150402.12 
Nhema, A.G. (2004). The Quest for Peace in Africa: Transformation, Democracy and Public Policy. Addis Ababa: OSSREA.

Sharma, P. (2016). "Soft Skills in non-formal education: building capacities of the youth." Dvv international, 83. Bonn, Germany: 110-113.

Stake, E, R. (2010). Qualitative Research: Studying How Things Work. New York: The Guilford Press.

Stanko, E. (2001). "The Day to Count: Reflections on a Methodology to Raise Awareness about the Impact of Domestic Violence in the UK. " Criminology and Criminal Justice, 1(2):215-226.

TGE. (1994). Ethiopian Education and Training Policy. Addis Ababa

Tilahun, W. (2011). The Adult Education Practice in Ethiopia. Addis Ababa.

Tigist Engdaw. (2018). Peace Education for Youth Violence Prevention in Africa. Holistic and Integrated Approach: Case Study of Ethiopian Schools. Lambert Academic Publications.

UNESCO. (1996). Learning: The treasure within (Report to UNESCO of the International Commission on Education for the $21^{\text {st }}$ century (highlights)). Paris: UNESCO. Available at http://www.unesco.org/delors/

UNESCO (1997a). Adult Education: the Hamburger Declaration: Agenda for the future. Hamburg: UIE 